\title{
The effect of salinity and temperature on survival and metamorphosis of megalops of the blue crab Callinectes sapidus
}

\author{
John D. Costlow, Jr. ${ }^{1}$ \\ Duke University Marine Laboratory, Beaufort, North Carolina, U.S. A.
}

\begin{abstract}
KURZFASSUNG: Die Wirkung von Salinität und Temperatur auf das Überleben und die Metamorphose der Megalopalarven der Blauen Krabbe Callinectes sapidus. Larven der Blauen Krabbe (Callinectes sapidus RATHBUN) wurden bei $25^{\circ} \mathrm{C}$ und $30 \% \mathrm{~S}$ (= p. p. m.) gezüchtet, bis das Megalopalarvenstadium erreicht war. Die Megalopalarven wurden sodann in 6 verschiedenen Salzgehalten und 4 verschiedenen Temperaturen gehalten, um die Wirkung von Salzgehalt und Temperatur sowie von deren Kombinationen auf Überlebensrate, Entwicklung und Metamorphose festzustellen. Bei $20^{\circ}, 25^{\circ}$ und $30^{\circ} \mathrm{C}$ überlebten über $70 \%$ der Megalopalarven in Medien von 10 bis $40 \%$ S. Bei $15^{\circ} \mathrm{C}$ betrug die Uberlebensrate 10 bis $50 \%$ in Salzgehalten von 20 bis $40 \%$. Die Megalopalarven metamorphosierten nicht bei $15^{\circ} \mathrm{C}$ und $10 \%$ sowie bei $20^{\circ} \mathrm{C}$ und $5 \%$. Die Dauer des Megalopastadiums schwankte von 5 Tagen bei $30^{\circ} \mathrm{C}$ bis zu 67 Tagen bei $15^{\circ} \mathrm{C}$. Die Temperatur beeinflußte die Lebensdauer der Megalopalarven stärker als der Salzgehalt. Bei $20^{\circ}$ und $30^{\circ} \mathrm{C}$ wurde die Dauer des Megalopastadiums durch veränderte Salinitätsbedingungen nicht beeinflußs. Bei $15^{\circ} \mathrm{C}$ bewirkte eine Erhöhung des Salzgehalts jedoch eine Verzögerung der Metamorphose des ersten Krabbenstadiums. Durch statistische Analysen sind die Wirkungen von Salzgehalt und Temperatur auf Sterblichkeit und Entwicklungsrate der Megalopalarven für eine größere Anzahl von Umweltsbedingungen, als sie im Laboratorium geprüft werden konnten, ermittelt worden, so daß die Überlebensrate der Megalopalarven innerhalb eines großen Temperatur- und Salzgehaltsbereiches mit großer Wahrscheinlichkeit vorausgesagt werden kann. Es ist anzunehmen, daß durch die zeitliche Verlängerung des Megalopastadiums und die hohe Überlebensrate in Gewässern mit niedriger Temperatur und hohem Salzgehalt ein Transport der Megalopalarven durch Meeresströmungen über weite Entfernungen ermöglicht wird. Diese Annahme würde unter anderem die Verbreitung dieser Gattung über einen großen Teil der Gewässer entlang der atlantischen Küste sowie im Golf von Mexiko erklären.
\end{abstract}

\section{INTRODUCTION}

Within recent years a number of studies have been made on the relationship between environmental factors and the larval development of the Brachyura or true crabs. ChamberlanN (1961) described the effect of variations in diet on larval development of Neopanope texana sayi (SMITH) and later (1962) considered the effect of a limited range of salinity and temperature on zoeae of Rhithropanopeus harrisii

\footnotetext{
1 Present address: Office of Naval Research, 429 Oxford St., London, W 1, England.
} 
(Gould). Costrow \& Bookhout (1962a), describing the larval development of Hepatus epheliticus (L.) in the laboratory, included observations on the effect of salinity on the survival and rate of development of the larvae. Studies on the development of larvae of Sesarma reticulatum $S_{A Y}$ included experiments to determine if photoperiod affected survival or rate of larval development (CosTlow \& BookHout 1962b). The effects of salinity, temperature, and the combined effects of salinity and temperature under controlled conditions of the laboratory have been described for the larvae of several additional species of crabs (Costrow, Bookhout \& Monroe 1960, 1962, 1966).

Within the Portunidae, which include the blue crab Callinectes sapidis RathBun, relatively little is known about the influence of environmental factors on development of the larvae. SANDOZ \& ROGERS (1944) studied the effect of salinity, temperature, and light on hatching, molting, and survival of the zoeae of C. sapidus but were unable to maintain the larvae beyond the third zoeal stage. In a later study by SANDOZ \& Rogers (1948), megalops of C. sapidus obtained from the plankton were used to determine the effect of salinity and temperature on molting and survival. The first successful rearing of the blue crab, from hatching to the first crab stage, included observations on the effect of a limited range of salinity and temperature, but because of mortality through all seven zoeal stages, the number of megalops which remained in the experimental series was extremely small (CostLow \& BookHout 1959).

The present study was undertaken to examine further the effect of salinity, temperature, and the combined effects of salinity and temperature, on survival, rate of development, and metamorphosis of megalops of C. sapidus reared from hatching under controlled conditions in the laboratory.

\section{METHODS}

Larvae of the blue crab, C. sapidus RATHBUN, were hatched from eggs removed from the female and maintained at 30 p.p.t., $25^{\circ} \mathrm{C}$ on an Eberbach variable-speed shaker following the method described by CostLow \& Booknout (1960). At the time of hatching the first stage zoeae were removed to mass culture bowls containing filtered sea water of the same salinity and temperature and reared in the manner described by Costlow \& Bookнout (1959).

When the megalops stage was reached the larvae were removed and maintained at six experimental salinities: 5, 10, 20,30, 35, and 40 p.p.t. The larvae were transferred directly from 30 p.p.t. to salinities of 20,35 , and 40 p.p.t. In the salinities of 5 and 10 p.p.t., the megalops were transferred from the rearing salinity of 30 p.p.t. to 20 p. p.t. for four hours and then moved to either 10 p.p.t. or 5 p.p.t. The temperature of the water was then gradually changed to one of four experimental temperatures: $15^{\circ}, 20^{\circ}, 25^{\circ}$, and $30^{\circ} \mathrm{C}$. The megalops were maintained individually in plastic compartmented boxes on variable-speed shakers, 110 oscillations per minute.

The megalops were checked daily for mortality and time of metamorphosis and transferred to clean compartmented boxes containing freshly filtered sea water of the 
same temperature and salinity. Recently hatched Artemia nauplii were added each day.

\section{RESULTS}

Table 1 gives the original number of megalops of C. sapidus maintained in each of the 23 combinations of salinity and temperature, the number and percentage which survived to the first crab stage, and the minimum, maximum, and average time required for metamorphosis.

Table 1

Number of larvae, number and percentage which metamorphosed to the first crab, and time required for development of megalops of Callinecies sapidus maintained at different salinitytemperatures

\begin{tabular}{|c|c|c|c|c|c|c|c|c|}
\hline \multirow{2}{*}{$\begin{array}{l}{ }^{\circ} \mathrm{C} \\
-- \\
15\end{array}$} & \multirow{2}{*}{$\begin{array}{c}\text { Salinity } \\
\text { (p.p.t.) }\end{array}$} & \multirow{2}{*}{$\begin{array}{l}\text { Number } \\
\text { of Iarvae } \\
\\
20 \\
22 \\
19 \\
20 \\
20\end{array}$} & \multicolumn{2}{|c|}{$\begin{array}{c}\text { Metamorphosed } \\
\text { larvae } \\
\text { (number percent) }\end{array}$} & \multicolumn{2}{|c|}{$\begin{array}{c}\text { Mortality } \\
\text { (number percent) }\end{array}$} & \multicolumn{2}{|c|}{$\begin{array}{l}\text { Total days to first crab } \\
\text { range average }\end{array}$} \\
\hline & & & $\begin{array}{r}0 \\
3 \\
8 \\
10 \\
2\end{array}$ & $\begin{array}{c}0 \\
13.6 \\
42.1 \\
50.0 \\
10.0\end{array}$ & $\begin{array}{l}20 \\
19 \\
11 \\
10 \\
18\end{array}$ & $\begin{array}{r}100.0 \\
86.4 \\
57.9 \\
50.0 \\
90.0\end{array}$ & $\begin{array}{c}- \\
30-39 \\
39-49 \\
37-55 \\
49-67\end{array}$ & $\begin{array}{c}- \\
34.0 \\
44.3 \\
46.3 \\
58.0\end{array}$ \\
\hline 20 & $\begin{array}{r}5 \\
10 \\
20 \\
30 \\
35 \\
40\end{array}$ & $\begin{array}{l}20 \\
20 \\
20 \\
20 \\
20 \\
20\end{array}$ & $\begin{array}{r}0 \\
14 \\
19 \\
18 \\
18 \\
15\end{array}$ & $\begin{array}{r}0.0 \\
70.0 \\
95.0 \\
90.0 \\
90.0 \\
75.0\end{array}$ & $\begin{array}{r}20 \\
6 \\
1 \\
2 \\
2 \\
5\end{array}$ & $\begin{array}{r}100.0 \\
30.0 \\
5.0 \\
10.0 \\
10.0 \\
25.0\end{array}$ & $\begin{array}{c}- \\
14-23 \\
12-18 \\
13-22 \\
13-26 \\
17-24\end{array}$ & $\begin{array}{l}- \\
17.6 \\
14.5 \\
15.2 \\
18.4 \\
19.1\end{array}$ \\
\hline 25 & $\begin{array}{r}5 \\
10 \\
20 \\
30 \\
35 \\
40\end{array}$ & $\begin{array}{r}9 \\
19 \\
20 \\
80 \\
20 \\
20\end{array}$ & $\begin{array}{r}2 \\
15 \\
17 \\
80 \\
19 \\
20\end{array}$ & $\begin{array}{r}22.2 \\
78.9 \\
85.0 \\
100.0 \\
95.0 \\
100.0\end{array}$ & $\begin{array}{l}7 \\
4 \\
3 \\
0 \\
1 \\
0\end{array}$ & $\begin{array}{r}77.8 \\
21.1 \\
15.0 \\
0.0 \\
5.0 \\
0.0\end{array}$ & $\begin{array}{r}10-13 \\
9-12 \\
8-11 \\
6-12 \\
7-9 \\
7-11\end{array}$ & $\begin{array}{r}11.5 \\
10.4 \\
8.9 \\
8.4 \\
7.6 \\
8.8\end{array}$ \\
\hline 30 & $\begin{array}{r}5 \\
10 \\
20 \\
30 \\
35 \\
40\end{array}$ & $\begin{array}{l}22 \\
20 \\
20 \\
14 \\
20 \\
20\end{array}$ & $\begin{array}{r}9 \\
19 \\
18 \\
12 \\
20 \\
20\end{array}$ & $\begin{array}{r}40.9 \\
95.0 \\
90.0 \\
85.7 \\
100.0 \\
100.0\end{array}$ & $\begin{array}{r}13 \\
1 \\
2 \\
2 \\
0 \\
0\end{array}$ & $\begin{array}{r}59.1 \\
5.0 \\
10.0 \\
14.3 \\
0.0 \\
0.0\end{array}$ & $\begin{array}{l}7-9 \\
5-8 \\
5-11 \\
5-8 \\
5-8 \\
5-7\end{array}$ & $\begin{array}{l}7.8 \\
6.2 \\
6.2 \\
6.6 \\
5.9 \\
5.9\end{array}$ \\
\hline
\end{tabular}

As shown in Table 1 and Figure 1, some megalops survived to the first crab in all salinity-temperature combinations other than $15^{\circ} \mathrm{C}, 10$ p.p.t. and $20^{\circ} \mathrm{C}, 5$ p.p.t. At $25^{\circ}$ and $30^{\circ} \mathrm{C}$, in salinities of 10 to 40 p.p.t., survival ranged from 78.9 to 100 percent. At $20^{\circ} \mathrm{C}$, in all salinities except 5 p.p.t., survival to the first crab ranged from 70 to 90 percent.

As shown in Figure 2, the time required for metamorphosis of the megalops varied considerably. The most pronounced effect of low temperature, extension of the 


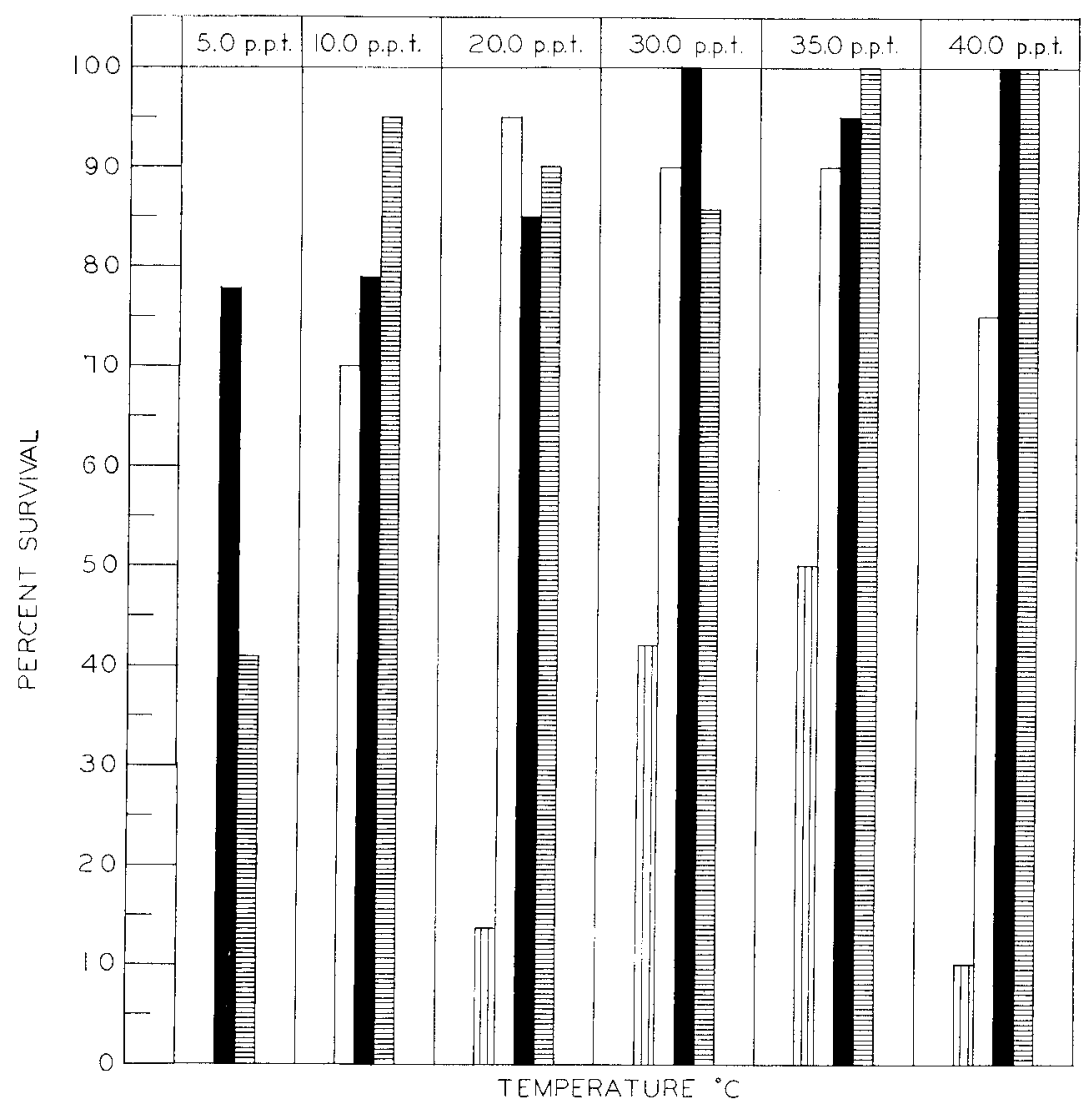

Fig. 1: Percentage survival to the crab stage of megalops of Callinectes sapidus maintained under 23 different combinations of salinity and temperature. Vertical lines: $15^{\circ} \mathrm{C}$; clear: $20^{\circ} \mathrm{C}$; solid: $25^{\circ} \mathrm{C}$; horizontal lines: $30^{\circ} \mathrm{C}$

duration of the megalops stage, was at $15^{\circ} \mathrm{C}$. As the salinity was increased from 20 to 40 p.p.t. the length of megalops duration was further increased in the larvae maintained at $15^{\circ} \mathrm{C}$. The average time for metamorphosis at $15^{\circ} \mathrm{C}, 20$ p.p.t. was 34 days

Table 2

Q10 values for time of development of megalops of Callinectes sapidus maintained at different temperature-salinity combinations

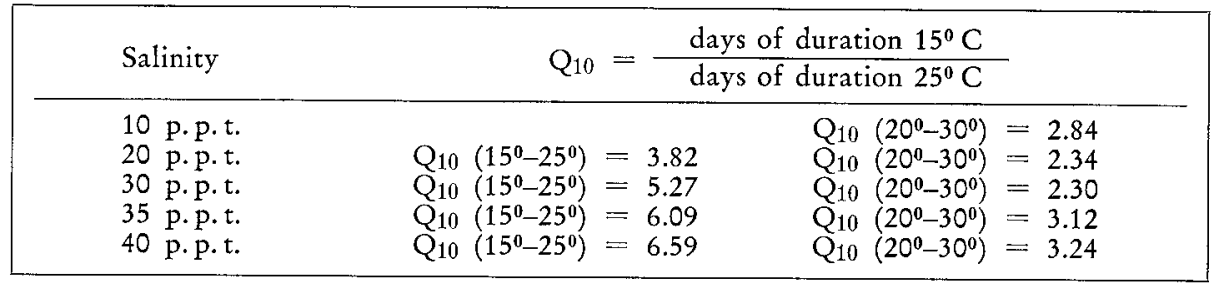


(range, 30 to 39 days) and 58 days (range, 49 to 67 days) at $15^{\circ} \mathrm{C}, 40$ p.p.t. The pronounced effect of temperature in extending the duration of the megalops stage, coupled with salinity, was not as apparent in the other salinity-temperature combinations. Length of larval life was increased slightly in higher salinities in the series

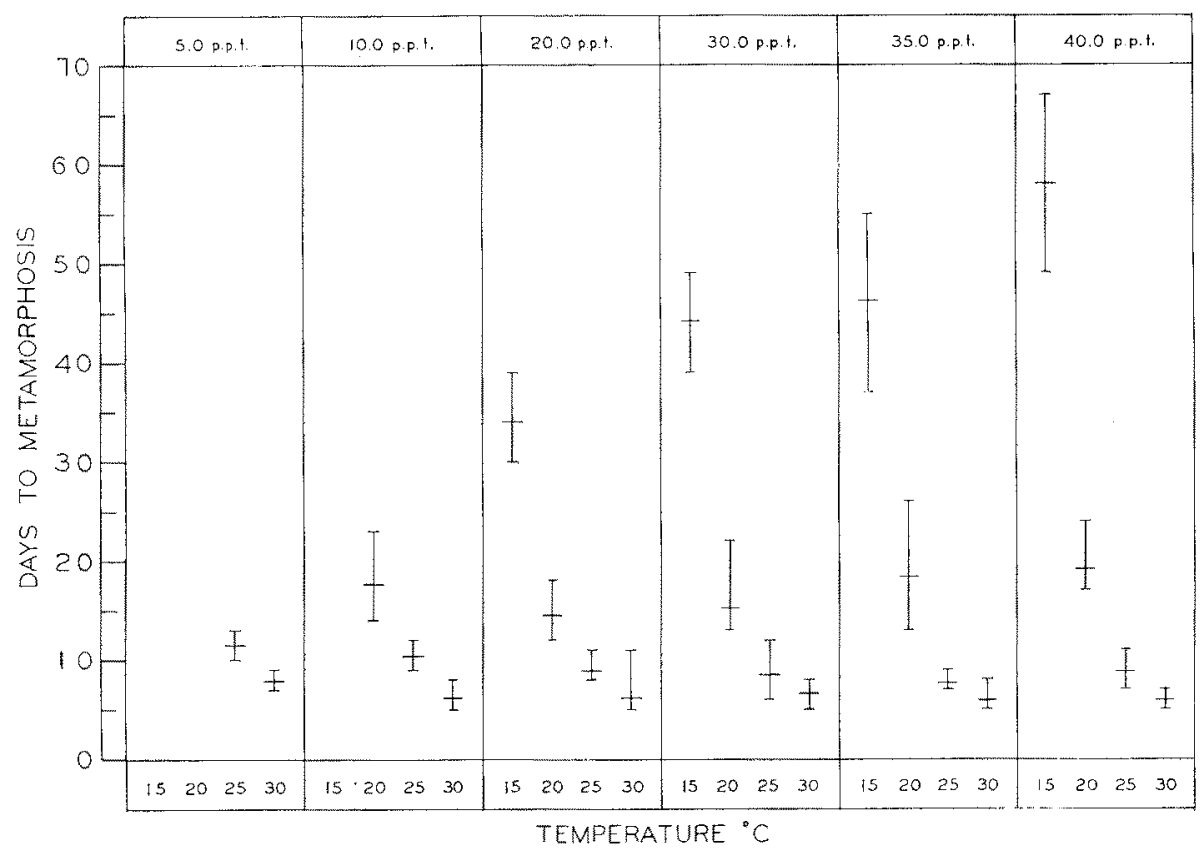

Fig. 2: Duration of megalops stage of Callinectes sapidus maintained at 23 different combinations of salinity and temperatures. The vertical line indicates the range and the middle horizontal bar the mean time to metamorphosis

of megalops reared at $20^{\circ} \mathrm{C}$, but at $25^{\circ}$ and $30^{\circ} \mathrm{C}$ there was no significant difference in duration of the megalops stage at 5 and 40 p.p.t. This general trend is perhaps best illustrated by a comparison of the $Q_{10}$ values for duration of the megalops stage given in Table 2.

\section{DISCUSSION}

Studies on the effect of environmental factors on growth and survival of the blue $\mathrm{crab}$, Callinectes sapidus, have been limited and confined largely to the adult stages. Immature and adult crabs have been reported frequently from brackish waters and are known to survive in dilutions of seawater for considerable periods of time (Darnell 1959, Gunter 1938, Newcombe 1945, Haefner \& Shuster 1964).

The migration of ovigerous female C. sapidus from brackish waters to waters of higher salinity has been observed for many years (CHURCHIL 1919) and has contributed to the hypothesis that salinity is a dominant factor affecting hatching, larval 
development, and survival. SANDOZ \& ROGERS (1944), attempting to rear the larval stages of the blue crab under controlled conditions in the laboratory, found that the largest percentage of normal, first stage zoeae hatched in salinities of 23 to 30 p.p.t., $19^{0}$ to $29^{\circ} \mathrm{C}$. At salinities below or above these limits, the majority of the larvae hatched as "pre-zoeae" and failed to survive (SANDOz \& Rogers 1944). Although none of the larvae survived beyond the third zoeal stage, a small percentage developed through the first and second zoeal stages in salinities of 18 to 29 p.p.t., $19^{0}$ to $29^{\circ} \mathrm{C}$ (SANDoz \& Rogers 1944). Cos'tlow \& Bookhout (1959) were able to maintain the larvae through all developmental stages in the laboratory. They reported that survival to the first crab occurred in salinities of 20.1 to 31.1 p.p.t. but not below 20.1 p.p.t. The time of zoeal development was not significantly different in salinities of 20.1 to 31.1 p.p.t., but a greater length of time was required for megalops development above 31.1 p.p.t.

The studies of SANDoz \& Rogers (1944) and Costlow \& Bookhout (1959) have indicated that an extremely small percentage of blue crab larvae survive to the crab, even in the salinity-temperature combinations which might be considered optimum. Subsequent research on the larvae (CostLow, unpublished) has further emphasized that survival is also extremely variable in egg masses obtained from different female crabs and in eggs hatched at different times of the year. Most of the mortality occurs during the early stages of zoeal development, but since replications and statistical treatment are not possible, the data should not be used to make correlations between survival or length of larval development and any one environmental factor or a combination of factors. By the time the megalops stage is reached, however, survival and rate of development are consistent within different series of larvae maintained under the same laboratory conditions (Costiow 1963a, b). Thus, it should be possible to maintain the megalops under different environmental conditions and, from the survival and time required for development to the crab, postulate how these two environmental factors, acting independently as well as through interaction, affect this portion of the life history of the blue crab.

\section{Survival}

Complete development of all larval stages has been shown to be affected by salinity and temperature for several species of Brachyura. The larvae of Sesarma cinereum completed metamorphosis to the first crab at 20.1 and 26.7 p.p.t. but not at 12.5 or 31.1 p.p.t. (Costlow, Bookhout \& Monroe 1960). Panopeus herbstii larvae were reared successfully at $20.1,26.5$, and 31.1 p. p.t. but did not survive at 12.5 p. p.t. (Costlow, Bookhout \& Monroe 1962). Rhitbropanopeus harrisii, normally found in low salinity waters, completed development in salinities of 2.5 to 40 p.p.t. but had the highest survival in 15 and 25 p.p.t. (Costlow, Bookhout \& Monroe 1966). Costzow \& Bookнout (1962a), describing the larval stages of Hepatus epheliticus, found that the larvae developed only in a limited range of higher salinities. At 25 p.p.t. the larvae reached the megalops stage but did not complete metamorphosis to the first crab. At 30 and 35 p.p.t., some larvae did reach the first crab stage with 
a higher percentage of survival at the higher salinity. At 20 and 40 p.p.t. there was no survival to the crab nor did the zoeae complete the normal number of stages to the megalops. Larvae of $S$. cinereum and $P$. berbstii generally had a higher percentage of survival as the temperature increased. Survival of $R$. harrisii larvae, however, was increased in lower temperatures coupled with higher salinities. Below 25 p.p.t., however, the percentage of survival increased with an increase in temperature (CosTLOW, BOOKHOUT \& MONROE 1966).

In the present study on megalops of $C$. sapidus, survival was similar at temperatures of 20,25 , and $30^{\circ} \mathrm{C}$ with the exception of the larvae maintained at 5 p.p.t. At $15^{\circ} \mathrm{C}$, in salinities other than 5 p.p.t., survival never exceeded 50 percent and, as the salinity was increased or reduced from 35 p.p.t., there was a reduction in the number of megalops which survived to complete metamorphosis (Fig. 1). Sandoz \& ROGERs (1948), although they did not give data for the survival of megalops of C. sapidus obtained from the plankton and maintained at various combinations of temperature and salinity, did show some survival to the megalops in salinities as low as 10 p.p.t., 11 to $17^{\circ} \mathrm{C}$. In the present study there was a tendency for the percentage survival of the megalops to decrease with lower temperatures when maintained in salinities of 5, 10, and 20 p.p.t. (Fig. 1). Thus, at 20 p.p.t., some megalops survived at all four temperatures, including $15^{\circ} \mathrm{C}$. At 10 p.p.t. 95 percent of the larvae survived at $30^{\circ} \mathrm{C}, 77$ percent at $25^{\circ} \mathrm{C}$, and 69 percent at $20^{\circ} \mathrm{C}$, but none of the megalops metamorphosed at $15^{\circ} \mathrm{C}$. At the lowest experimental salinity, 5 p. p.t., larvae survived at 30 and $25^{\circ} \mathrm{C}$ but not at $20^{\circ} \mathrm{C}$.

\section{Rate of development}

Temperature has been shown to have a direct affect on the rate of larval development for a number of species of Brachyura reared under controlled laboratory conditions. In general, a reduction in temperature of 10 degrees, from $30^{\circ}$ to $20^{\circ} \mathrm{C}$, has doubled the time required for complete larval development. Controlled temperatures lower than $20^{\circ} \mathrm{C}$ have seldom been used in laboratory studies on crab larvae. ChAmberlain (1962), who maintained a small number of Rhitbropanopeus harrisii zoeae at $15^{\circ}$ and $24^{\circ} \mathrm{C}$, reported an increase in duration of the four zoeal stages at the lower temperature. He considered only three salinities (3, 6, and 10 p.p.t.), however, and gave no data for duration of the megalops stage. Although the study of SANDOZ \& Rogers (1948) employed two ranges of temperature, $25^{\circ}$ to $29^{\circ} \mathrm{C}$ and $11^{\circ}$ to $17^{\circ} \mathrm{C}$, the origin of the megalops from the plankton permitted only a rough estimate of the age of the larvae at the time of collection. A comparison of their results with those of the present study indicates that even if the suggested 2 to 3 days are added to their data for the duration of megalops life, the discrepancy is still considerable. For example, in the present study the megalops required an average of 44.3 days to metamorphosis when maintained at 30 p.p.t., $15^{\circ} \mathrm{C}$. SANDoz \& Rogers (1948) gave 5.25 days for comparable development when the larvae were maintained at 31.1 p.p.t., $11^{\circ}$ to $17^{\circ} \mathrm{C}$. It must be assumed that the megalops collected by them had spent considerable time in the plankton prior to the experiment. 
Previous studies on development of crab larvae have indicated considerable variation in the effect of salinity on duration of the larval stages. The length of zoeal life of Sesarma cinereum was prolonged by a reduction in salinity and although the megalops stage followed this trend, the results were not as definite and there was overlapping in the time required for development of the megalops at different salinities (Costlow, Bookhout \& Monroe 1960). Although development of the larvae of Panopeus herbstii was delayed by reduced salinities, the rate of development in relation to differences in salinity varied less than in the larvae of $S$. cinereum (CostLow, Bоокноuт \& Monroe 1962) and larvae did develop successfully over a wider range of salinities. The time required for development of four zoeal stages and one megalops of $R$. harrisii was not affected significantly by salinities of 5 to 35 p.p.t. As opposed to these findings for larvae of estuarine species, the larval development of a crab normally found only in off-shore waters of higher salinity, Hepatus epheliticus, was similar at 30 and 35 p.p.t. At 25 p.p.t. considerably more time was required for the zoeae to attain the megalops stage and at 20 p.p.t., the zoeae were unable to complete development to the megalops (CosTlow \& Boокноuт 1962a).

As shown in Table 2, the $Q_{10}$ for duration of the megalops stage of C. sapidus at $15^{\circ}$ to $25^{\circ} \mathrm{C}$ ranged from 3.82 to 6.59 and at $20^{\circ}$ to $30^{\circ} \mathrm{C}$ from 2.84 to 3.24 . With an increase in salinity at $15^{\circ}$ to $25^{\circ} \mathrm{C}$ this value increased well beyond the 2.0 to 3.0 which is generally accepted for biological systems (Table 2). Because of the unknown age of the megalops of C. sapidus used by SANDOZ \& Rogers (1948) a direct comparison of duration or $\mathrm{Q}_{10}$ values cannot be made. If one assumes, however, that the 2200 larvae which they collected within a 20 minute period represented a reasonably limited range in age, their results are directly opposite to those of the present study. They showed an increase in duration of the megalops stage with decreasing salinity in both temperature series. In the present study, duration of megalops life increased significantly with an increase in salinity at $15^{\circ} \mathrm{C}$, but not at the other temperature. Further explanation of the high $\mathrm{Q}_{10}$ values must await additional experiments.

\section{Estimation of environmental effects}

Earlier studies on the larval development of the Brachyura have attempted to use statistical analysis of factorial designs to predict the mortality and duration of larval stages which might be expected under a greater number of salinity-temperature combinations than are possible to observe in the laboratory. The same general experimental design has been followed in the present study on megalops of C. sapidus, using a $6 \times 4$ factorial. This approach employs 6 levels of salinity and the 4 levels of temperature, to give a total of 24 combinations of the two environmental conditions which were used to maintain the larvae. Because one of the combinations (5 p.p.t. $-15^{\circ} \mathrm{C}$ ) was not used, 23 combinations were actually tested under experimental conditions in the laboratory. The analysis of either duration of larval life, or mortality, and the relationship to salinity, temperature, and salinity-temperature interaction was the fitting of a response surface (Box \& Youle 1955, Costlow, Boоkнout \& Monroe $1960,1962,1966)$ where the response was taken to be $\mathrm{Y}=\operatorname{arcsine} \sqrt{\text { percentage }}$ 
mortality or $\mathrm{Y}=$ duration in days. The functional form fitted was a full quadratic in salinity and temperature.

In the plotting of the contours of mortality, or of days of duration of the megalops stage, the choice of contours was in part dictated by the computer program used to do the computations (Figs. 3 and 4). The program required that a constant increment be used once an initial value had been set. Thus, the mortality contours represent even

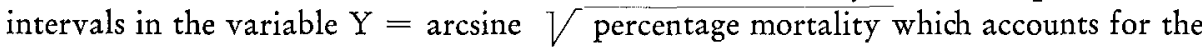
uneven contours labeled $6.7 \%$ and $93.3 \%$. Similar compromises were required in the computation of the 5 day intervals of the duration contours.

Individual regression coefficients of the linear and quadratic effects of salinity $\left(S, S^{2}\right)$, the linear and quadratic effects of temperature $\left(T, T^{2}\right)$, and the interaction between the linear components of salinity and temperature $(S \times T)$, were determined for mortality and for duration of the megalops stage. The individual regression coefficients were compared with their respective standard errors as a test of significance. A summary of these tests follows:

Table 3

Statistical analysis

\begin{tabular}{|clcl|}
\hline Mortality & Significance & Duration & Significance \\
\hline $\mathrm{S}$ & $1 \%$ level & $\mathrm{S}$ & not significant \\
$\mathrm{S}^{2}$ & $1 \%$ level & $\mathrm{S}^{2}$ & $5 \%$ level \\
$\mathrm{T}$ & $1 \%$ level & $\mathrm{T}$ & $1 \%$ level \\
$\mathrm{T}^{2}$ & $1 \%$ level & $\mathrm{T}^{2}$ & $1 \%$ level \\
$\mathrm{S} \times \mathrm{T}$ & not significant & $\mathrm{S} \times \mathrm{T}$ & not significant \\
\hline
\end{tabular}

Thus, as indicated in the summary, all factors other than the interaction of salinity and temperature would be expected to contribute to the mortality of the megalops of C. sapidus. Within a wide range of salinity and temperature (11 to 40 p.p.t., 18 to $35^{\circ}$ C) $25 \%$ mortality or less is predicted (Fig. 3). A steady increase in mortality could be expected, however, if a decrease in salinity were accompanied by a decrease in temperature. The absence of any effect due to interaction of salinity and temperature is also indicated by the shape of the contour for mortality. The contours approximate perfect circles and are not skewed as would be expected if interaction were a significant factor in mortality of the larvae.

The linear and quadratic effects of temperature were highly significant in the duration of the megalops stage (Fig. 4). The quadratic effect of salinity was significant only at the $5 \%$ level and the linear effects of salinity was not significant. Although the tests indicated that the combined effect of salinity and temperature $(S \times T)$ was not a significant factor in the duration of the megalops stage, the skewing of the contours, as well as an examination of Figure 2, suggest that within the one temperature series, $15^{\circ} \mathrm{C}$, effects on duration result from interaction between salinity and temperature. At $20^{\circ}, 25^{\circ}$, and $30^{\circ} \mathrm{C}$ the duration was not affected by a decrease or increase in salinity. At $15^{\circ} \mathrm{C}$, however, the increase in duration of the megalops with an increase in salinity was pronounced. One can only assume that in the statistical 


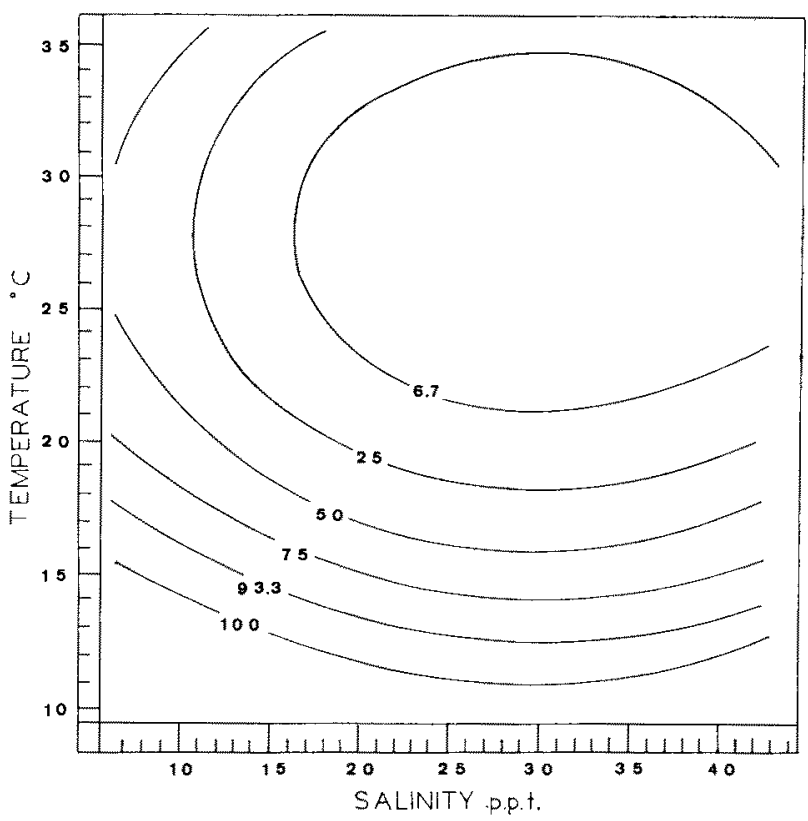

Fig. 3: Estimation of percentage mortality of megalops stage of Callinectes sapidus based on fitted response surface to observed mortality under 23 different combinations of salinity and temperature

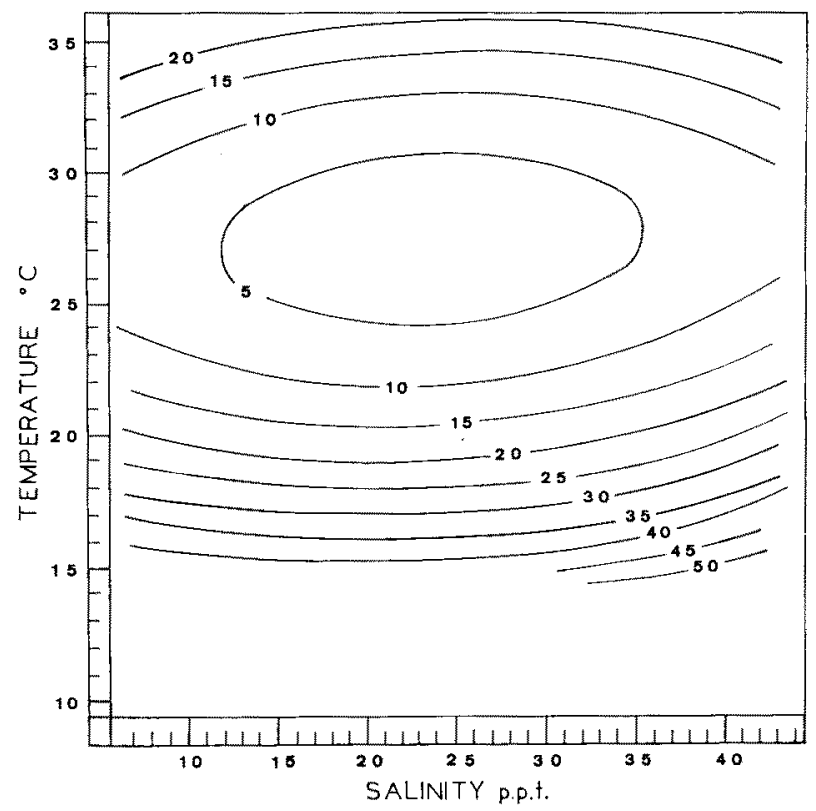

Fig. 4: Estimation of duration of megalops stage of Callinectes sapidus based on fitted response surface to observed length of megalops life under 23 different combinations of salinity and temperature 
treatment of all the data the significance of the portion dealing with the effect at $15^{\circ} \mathrm{C}$ was diminished by the averaging process over the other three temperatures.

\section{Ecological significance}

The relative abundance of larvae of C. sapidus in waters of different salinity has been a subject of discussion for a number of years. Hopkins (1943) noted that blue crab larvae were generally more abundant in waters of higher salinity in lower Chesapeake Bay. Pinschmid (1963) recorded large numbers of early stage zoeae of C. sapidus in the lower salinity waters of the Newport River estuary (Beaufort, N. C.) but found very few late zoeae or megalops stages within the estuary. A study of the plankton off the coast of North Carolina, South Carolina, Georgia, and Florida revealed that although large numbers of the early zoeae were in waters adjacent to the beaches, a still larger percentage of the early larvae were in the waters 20 miles from the coast (Nichols \& KenEY 1963). The actual numbers of megalops which were collected was small and the distribution from the beach to the waters 60 miles off-shore was similar. From the work of NicHOLS \& KENEY (1963) it would appear that normally the megalops of $C$. sapidus spend at least a portion of their life in waters of high salinity. In the present study survival was similar in salinities of 10.0 to 40 p.p.t. within a temperature range of $20^{\circ}$ to $30^{\circ} \mathrm{C}$. It should be noted that Nichols \& KENEY (1963) reported the greatest abundance of megalops during the period when water temperatures ranged from $27.3^{\circ}$ to $29.1^{\circ} \mathrm{C}$. In the laboratory 100 percent of the megalops survived at $30^{\circ} \mathrm{C}, 35 \mathrm{p}$.p.t. The period of least abundance in the natural environment was mid-winter when water temperatures varied from $14.3^{\circ}$ to $16.4^{\circ} \mathrm{C}$. Under laboratory conditions, 50 percent of the megalops maintained at $15^{\circ} \mathrm{C}$, 35 p. p.t. survived and metamorphosed to the first crab (Fig. 1).

From the present study one can postulate that survival and duration of the megalops stage of the blue crab in the natural environment are directly associated with the time of hatching, the time at which the megalops stage is reached in relation to seasonal changes in the water temperature, and the salinity of the water in which the final zoeal molt occurs. Although some early stage blue crab larvae may be found in waters off North Carolina in 8 months of the year (NICHoLs \& KENEY 1963), the first period of any great abundance is May when water temperatures are rising from $20^{\circ} \mathrm{C}$. On the basis of the time of development of the seven zoeal stages given by CostLow \& Bоокноuт (1959) the megalops stage should be reached by approximately midJune. Of the few larvae retained within the lower salinity waters of the estuary a large percentage would be expected to metamorphose to the first crab at temperatures of $25^{\circ} \mathrm{C}$. Larvae carried beyond the estuary to the higher salinity water of the ocean would have an even greater chance of survival during the summer months. If hatching were to occur in September, when water temperatures are decreasing from $25^{\circ} \mathrm{C}$, the same rate of development would result in metamorphosis during mid to late October when water temperatures are approaching $18.9^{\circ} \mathrm{C}$ off the coast of North Carolina (Nichols \& KENEY 1963). Metamorphosis of megalops in water of higher salinity should be delayed considerably by the gradual reduction in temperature, whereas 
those which had been carried back to the lower salinities of the estuary could complete metamorphosis to the first crab. The relatively high survival of megalops at $15^{\circ} \mathrm{C}$, 35 p.p.t., accompanied by the delay in metamorphosis to the first crab, may have contributed to the distribution of this species in the estuaries along a major portion of the Atlantic and Gulf Coasts. The extended duration of the megalops stage in cold waters of high salinity would permit the larvae to be carried relatively long distances by ocean currents. Megalops which are carried back into the estuaries could then metamorphose under environmental conditions which are more favorable to the sur vival of the early crab stages.

\section{SUMMARY}

1. Megalops of the blue crab, Callinectes sapidus Rathbun, reared from hatching through all zoeal stages at $25^{\circ} \mathrm{C}, 30$ p.p.m., were maintained in 23 combinations of salinity and temperature until metamorphosis to determine the effect of salinity and temperature and the combined effect of salinity and temperature on survival and rate of development.

2. Survival of the megalops stage was similar at temperatures of $20^{\circ}, 25^{\circ}$, and $30^{\circ} \mathrm{C}$ with the exception of the larvae maintained at 5 and 10 p.p.m. At $15^{\circ} \mathrm{C}$, survival never exceed 50 percent.

3. In the lower salinities ( 5 and 10 p.p.m.) survival decreased with a decrease in temperature.

4. The most pronounced effect of temperature in delaying the time of metamorphosis was observed in megalops maintained at $15^{\circ} \mathrm{C}$. As the salinity increased from 20 to 40 p.p.m., the duration of the megalops stage was further extended at $15^{\circ} \mathrm{C}$. This effect was not observed at other salinity-temperature combinations.

5. Statistical analysis of factorical design was used to predict the mortality and duration of the megalops stage which might be expected under a greater number of salinity-temperature combinations than are feasible to observe in the laboratory. The results of the analysis and their possible significance are discussed.

6. The hypothesis is presented that survival and duration of the megalops of C. sapi$d u s$ in the natural environment are directly associated with the time of hatching, the time at which the megalops stage is reached in relation to seasonal changes in water temperatures, and the salinity of the water in which the final zoeal molt occurs. The delay of metamorphosis in waters of high salinity and low temperature may have contributed to the distribution of this species in the estuaries along a major portion of the Atlantic and Gulf Coasts of the United States.

\section{ACKNOWLEDGEMENTS}

These studies were aided by a contract (14-17-0002-155) between the Bureau of Commercial Fisheries and Duke University. I wish to thank Dr. R. J. Monroe, Department of Experimental Statistics, North Carolina State College, Raleigh, N. C., for his assistance with the statistical portion of the study. 


\section{LITERATURE CITED}

Box, G. E. P. \& Youle, P. V., 1955. The exploration and exploitation of response surfaces: An example of the link between the fitted surface and the basic mechanism of the system. Biometrics 11, 287-323.

Chamberlain, N. A., 1961. Studies on the larval development of Neopanope texana sayi (SmiтH) and other crabs of the family Xanthidae (Brachyura). Tech. Rep. Chesapeake Bay Inst. 22, 1-35.

- 1962. Ecological studies of the larval development of Rbithropanopeus harrisii (Xanthidae, Brachyura). Tech, Rep. Chesapeake Bay Inst. 28, 1-47.

Churchill, E. P., 1919. Life history of the blue crab. Bull. Bur. Fish., Wash. 36, 96-123.

Costrow, J. D., Jr., 1963a. Regeneration and metamorphosis in larvae of the blue crab, Callinectes sapidus RaţвuN. J. exp. Zool. 152, 219-228.

- 1963b. The effect of eyestalk extirpation on metamorphosis of megalops of the blue crab, Callinectes sapidus Rathbun. Gen. comp. Endocr. 3, 120-130.

- \& Boокнout, C. G., 1959. The larval development of Callinectes sapidus Rathbun reared in the laboratory. Biol. Bull. mar. biol. Lab., Woods Hole 116, 373-396.

- 1960. A method for developing Brachyura eggs in vitro. Limnol. Oceanogr. 5, 212-225.

- 1962a. The larval development of Hepatus epheliticus (L.) under laboratory conditions. J. Elisha Mitchell scient. Soc. 78, 113-125.

- - 1962b. The larval development of Sesarma reticulatum SAY reared in the laboratory. Crustaceana 4, 281-294.

- - \& Monroe, R., 1960. The effect of salinity and temperature on larval development of Sesarma cinereum (Bosc) reared in the laboratory. Biol. Bull. mar. biol. Lab., Woods Hole 118, 183-202.

- - - 1962. Salinity-temperature effects on the larval development of the crab, Panopeus herbstii MrLnE-EDwARDs, reared in the laboratory. Physiol. Zool. 35, 79-93.

- - - 1966. Studies on the larval development of the crab, Rbithropanopeus harrisii Gousd. 1. The effect of salinity and temperature on larval development. Physiol. Zool. 39, $81-100$.

Darnell, R. M., 1959. Studies of the life history of the blue crab (Callinectes sapidus Rathbun) in Louisiana waters. Trans. Am. Fish. Soc. 88, 294-304.

Gunter, G., 1938. The common blue crab in fresh water (Callinectes sapidus). Science, N. Y. 87, 87-88.

Haefner, P. A. \& Shuster, C. N., Jr., 1964. Length increments during terminal molt of the female blue crab, Callinectes sapidus, in different salinities. Chesapeake Sci. 5, 114-118.

Hopkins, S. H., 1943. The external morphology of the first and second zoeal stages of the blue crab, Callinectes sapidus Ratłbun. Trans. Am. Microsc. Soc. 62, 85-90.

Newcombe, C. L., 1945. The biology and conservation of the blue crab, Callinectes sapidus Rathbun. Educ. Ser. Va Fish. Lab. 4, 1-39.

Nichols, P. R. \& Keney, P. M., 1963. Crab larvae (Callinectes), in plankton collections from cruises of M/V Theodore N. Gill, South Atlantic Coast of the United States, 1953-54. Spec. scient. Rep. U. S. Fish. Wildl. Serv. 448, 1-14.

Pinschmidt, W. C., Jr., 1963. Distribution of crab larvae in relation to some environmental conditions in the Newport River Estuary, North Carolina. Manuscr. Duke Univ. (unpubl.) 1963, 1-111.

SANDOZ, M. \& Rogers, R., 1944. The effect of environmental factors on hatching, moulting, and survival of zoea larvae of the blue crab, Callinectes sapidus Rathbun. Ecology 25, 216-228.

- - 1948. The effect of temperature and salinity on moulting and survival of megalops and postlarval stages of the blue crab, Callinectes sapidus. Manuscr. Va Fish. Lab. (unpubl.) 1948, 1-11. 


\section{Discussion following the paper by CostLow}

WEBB: What criteria are used to determine the death point of the megalops?

Costrow: The heart of the zoeae and megalops is quite apparent. When it ceases to beat, one is reasonably certain that the animal is dead.

WEBB: Have megalops in which the heart has stopped ever been known to recover?

Costlow: We have not observed it to resume beating after the "death point". 